Acta vet. scand. $1973,14,254-262$.

From the Department of Clinical Biochemistry and the Department of Animal Nutrition, Hygiene and Genetics, Royal Veterinary College, and the Research Institute of National Defence, Department 4, Stockholm, Sweden.

\title{
IODINE CONTENT IN COLOSTRUM AND MILK OF COWS AND SOWS*
}

By

\author{
K. Iwarsson, G. Bengtsson and L. Ekman
}

IWARSSON, K., G. BENGTSSON and L. EKMAN: Iodine content in colostrum and milk of cows and sows. Acta vet. scand. 1973, 14, 254-262. - The concentration of total iodine in colostrum and normal milk of cows and sows has been determined using a Technicon Autoanalyzer. In cows as well as in sows a lowering of the level of iodine in milk was observed during the first few days after parturition. At the first sampling within $8 \mathrm{hrs}$. after parturition the concentration of iodine in colostrum of cows from 2 herds was on average 3.4 and $2.4 \mu \mathrm{g} / 100 \mathrm{ml}$, respectively. Corresponding value for colostrum of the sows was $67 \mu \mathrm{g} / 100 \mathrm{ml}$. Based on informations about the composition of the food and daily food consumption it could be estimated that $0.5-1$ and $20-45 \%$ of the daily intake of iodine were secreted per 1 milk or colostrum of cows and sows, respectively. It can be concluded that the mammary gland of the sow has a considerably higher ability to concentrate iodine than that of the cow. Furthermore the concentration mechanism is more efficient immediately after parturition than at later stages of lactation.

i odine; colostrum; milk; cows; sows.

Generally the content of nutrients including vitamins and trace elements in colostrum is adapted to cover the requirement of the newborn. Knowledge about the composition of colostrum as well as of normal milk at various stages of the early lactation period is essential for adequate dietetics of the newborn.

The element iodine is one of the essential micronutrients being secreted in milk. Its concentration in milk varies greatly depending on a number of factors among which the intake of iodine in the food seems to be of utmost importance. Inadequate

* This investigation was supported by grants from the Swedish Council for Forestry and Agricultural Research (A 3176/B 2331). 
iodine intake of the mother is usually reflected in reduced secretion of iodine in milk with subsequent undesirable effects on the offspring. The young growing animal is extremely sensitive to iodine deficiency. Morphological and functional changes of the thyroid gland of the newborn as well as a reduced growth may be the ultimate result of such a deficiency.

Knowledge about the changes of iodine secretion in milk at different stages of lactation is also important in the present era of environmental pollution with radioisotopes of iodine.

In the present study the results of determinations of total iodine in colostrum and normal milk from cows and sows at different stages of lactation are presented. Species differences in the ability of the mammary tissue to concentrate iodine have been observed (Brown-Grant 1961).

\section{MATERIAL AND METHODS}

Nine cows in a herd of 170 cows (Herd I) and 6 cows in a herd of 50 cows (Herd II) were used in the investigations. All cows were of the Swedish Red and White Breed. The age varied between 4 and 7 years. In both herds the cows were tied up and milked twice a day. The cows in Herd $I$ were given $7 \mathrm{~kg}$ hay, $1 \mathrm{~kg}$ dried beet pulp, 8-12 kg concentrates ${ }^{\star}$ according to milk yield, and $150 \mathrm{~g}$ mineral supplement (non iodized) per cow and day. Each cow had free access to a salt block containing $0.005 \%$ potassium iodide. The same mineral supplement was given during late pregnancy as during the period of lactation. Herd II were fed $3 \mathrm{~kg}$ hay, $8-10 \mathrm{~kg}$ concentrate mixture (pellets) ${ }^{\star \star}$ according to milk yield, and $8 \mathrm{~kg}$ silage. During the drying up period the cows were fed $2 \mathrm{~kg}$ of the concentrate mixture.

Five sows from an experimental herd of 16 sows of the Swedish landrace were used in the study. During late pregnancy and lactation periods the sows had free access to water and were

* Composition of the concentrate mixture: Oats $40 \%$, barley $40 \%$, cotton seed cake $7 \%$, soybean meal $5 \%$, peanut cake $4 \%$, rapeseed meal $4 \%$.

"* „Nötfor® - Kofoder 19“ manufactured by the Swedish Farmers' Purchasing and Selling Association (S.L.R.), Stockholm, Sweden. Composition: Oats $13 \%$, barley $14 \%$, wheat $10 \%$, rye $5 \%$, oil-cake mixture $15 \%$, draff $16 \%$, cococake $8 \%$, molasses $7 \%$, dried beet pulp $9 \%$, fodder lime $0.7 \%$, minerals $1 \%$, common salt $1 \%$ (50 mg $\mathrm{KI} / \mathrm{kg}$ ), vitamin concentrate $0.2 \%$. 
given $2.5 \mathrm{~kg}$ daily of a mixture of $90 \%$ oats and barley (1:1) and $10 \%$ of a protein-mineral-vitamin supplement ${ }^{*}$.

The cows as well as the sows selected in the herds were healthy and had no signs of mastitis during the sampling periods.

After parturition the calves were separated from the cows without having sucked. First sampling of milk from the cows was performed within $8 \mathrm{hrs}$. after parturition. Thereafter milk was sampled in the morning before ordinary milking at time intervals indicated in Figs. 1 and 2. Before taking the sample to be investigated the teats and the udder were cleaned with a dry paper towel. The first milk portion was discarded. Thereafter a $10-\mathrm{ml}$ sample of milk was taken in a plastic tube. All samples were taken from the same teat throughout the investigation.

Milk from the sows was obtained immediately after delivery from a teat randomly selected. The first milk portion was discarded. Then $8 \mathrm{ml}$ of milk was taken. Sampling took place at time intervals seen in Fig. 3. All milk samples were kept frozen until analysed.

Total iodine in milk was determined in an Autoanalyzer (Technicon Instruments Corp., USA). A technique described by the manufacturer (Technicon Laboratory Method File, N-56, 1969) for measuring protein-bound iodine in blood serum was used, excluding the step of resin treatment. The milk samples were centrifuged, and de-fatted milk was obtained. Two ml defatted milk was introduced into the analytical system at the regular analytical rate of 20 tests per hr. When analysing milk from the sows having an iodine concentration between 20 and $100 \mu \mathrm{g} / 100 \mathrm{ml}$ the standard sample pump tubing (I D 0.030 Shoulder colour Black) was replaced by a sample pump tubing ( 0.020 Shoulder colours Orange Yellow) giving a sample delivery of $0.16 \mathrm{ml} / \mathrm{min}$. The normal delivery is $0.32 \mathrm{ml} / \mathrm{min}$. The error of the method was determined at 3 different concentration ranges: $<1.0,1.1-20.0$ and $20.1-100 \mu \mathrm{g} / 100 \mathrm{ml}$. At a mean value of $0.6,8.2$ and $54 \mu \mathrm{g} / 100 \mathrm{ml}$ the errors were found to be $7.1 \%, 2.7 \%$ and $3.2 \%$, respectively. Error of the method was

* Suggex $\circledast$ manufactured by AB Lactamin, Stockholm. Composition: $10 \%$ dried skim-milk, $40 \%$ fish meal (70 to $74 \%$ crude protein), $26 \%$ meat meal (minimum $60 \%$ crude protein), $10 \%$ wheat bran, $8 \%$ ground limestone, $\mathbf{5 . 5} \%$ sodium chloride and trace elements and $0.5 \%$ vitamins. 
obtained by the formula $\sqrt{\frac{\sum d^{2}}{2 n}}$ where $d$ is the difference between duplicate determinations and $n$ the number of duplicate determinations.

\section{RESULTS}

The concentration of total iodine in milk of the cows in the 2 herds investigated during the first days after parturition is demonstrated in Figs. 1 and 2. There is a decline in the concentration from the first sampling occurring within $8 \mathrm{hrs}$. after parturition to the one performed 2 days later. The milk of the cows in Herd II showed from this time up to the last sampling day, 12 days after delivery, about the same concentration of iodine. In the milk from cows in Herd I, however, the concentration of total iodine increased from 2 days after parturition to the last sampling day, 4 weeks after parturition. A considerable variation in the concentration of iodine from individual cows at each sampling day is noticeable especially in cows in Herd I.

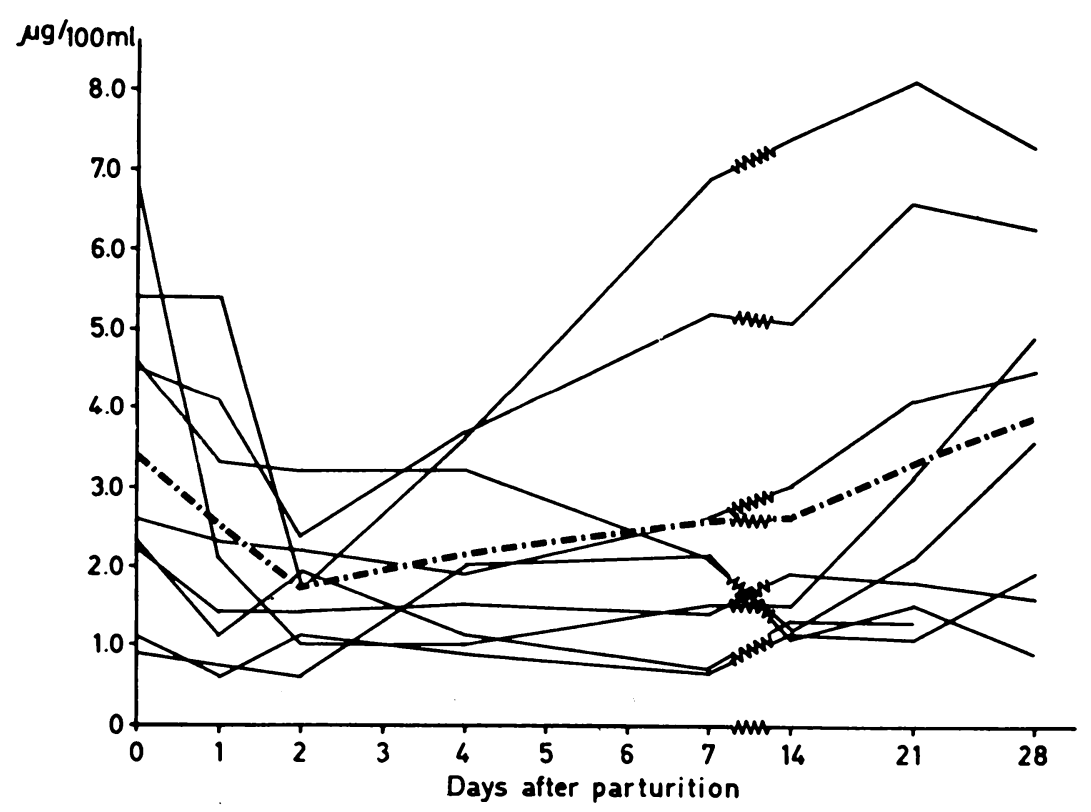

F i g u r e 1. Concentration of total iodine in milk of 9 cows in Herd I during the first 4 weeks of lactation. Samples at time 0 were taken within $8 \mathrm{hrs}$. after parturition. denotes the concentration in milk of individual cows, and values at various sampling occasions. 


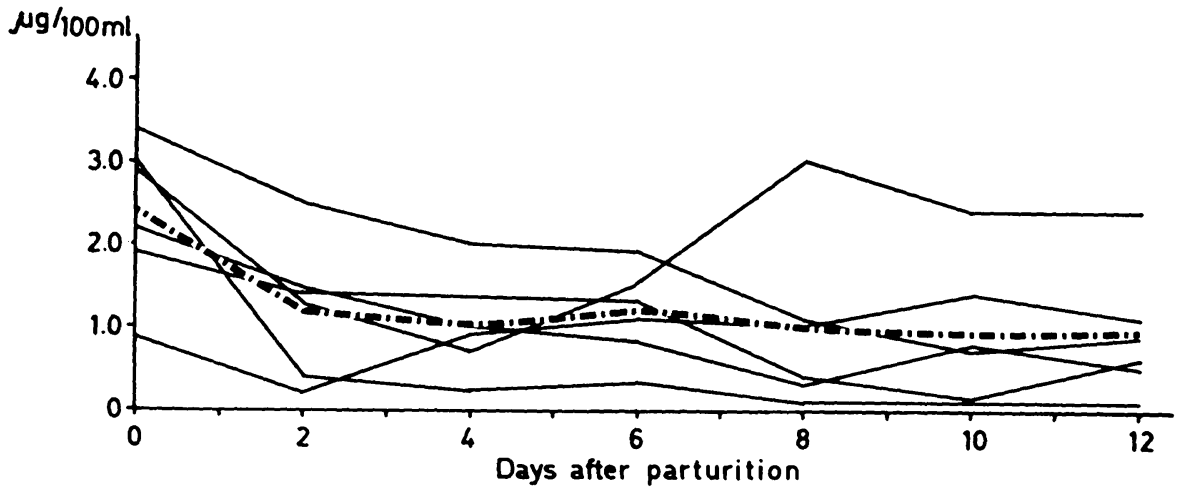

F i g u r e 2. Concentration of total iodine in milk of 6 cows in Herd II during the first 12 days of lactation. Samples at time 0 were taken within $8 \mathrm{hrs}$. after parturition. denotes the concentration in milk of individual cows, and values at various sampling occasions.

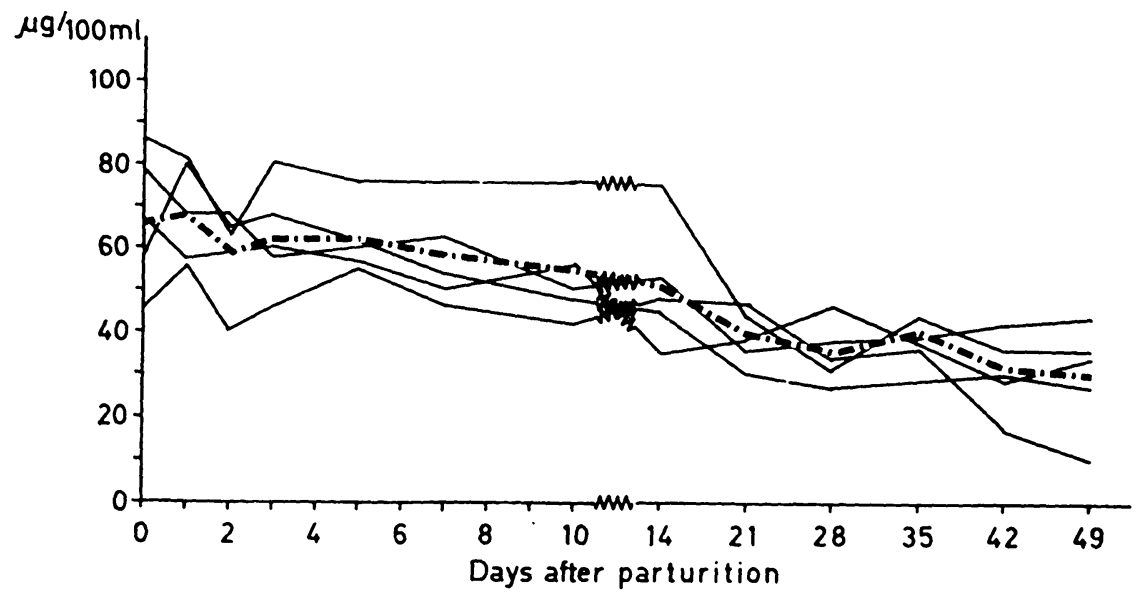

F i g u r e 3. Concentration of total iodine in milk of 5 sows during the first 7 weeks of lactation. Samples at time 0 were taken immediately after parturition. denotes the concentration in milk of individual sows, and minini the mean curve based on mean values at various sampling occasions. 
T a b l e 1. Total iodine concentration in milk $(\mu \mathrm{g} / 100 \mathrm{ml})$ of cows (Herds I and II) and sows at different times after parturition. Mean value and standard deviation are given.

\begin{tabular}{cccc}
\hline Day after parturition & \multicolumn{2}{c}{ Cows } & Sows \\
\cline { 2 - 4 } & $\begin{array}{c}\text { (Herd I, } \\
\mathrm{n}=9)\end{array}$ & $\begin{array}{c}\text { (Herd II, } \\
\mathrm{n}=6)\end{array}$ & $(\mathrm{n}=5)$ \\
\hline 0 & $3.4 \pm 2.0$ & $2.4 \pm 0.9$ & $67 \pm 16$ \\
2 & $1.7 \pm 0.8$ & $1.2 \pm 0.8$ & $59 \pm 12$ \\
$7-8$ & $2.6 \pm 2.1$ & $1.0 \pm 1.1$ & $58 \pm 12$ \\
$12-14$ & $2.6 \pm 2.2$ & $0.9 \pm 0.8$ & $51 \pm 15$ \\
28 & $3.9 \pm 2.3$ & & $35 \pm 8$ \\
49 & & & $30 \pm 13$ \\
\hline
\end{tabular}

It should be noted, however, that in general a cow having a high concentraition at one sampling day also shows a high concentration of iodine at other sampling days and vice versa.

Milk of sows had the highest concentration of total iodine during the first day after parturition (Fig. 3). About 24 hrs. after delivery the concentration was on average $67 \mu \mathrm{g} / 100 \mathrm{ml}$. From that day on the concentration decreased steadily up to the last sampling day 49 days after parturition when a mean value of $30 \mu \mathrm{g} / 100 \mathrm{ml}$ was recorded.

To facilitate a comparison of the values of the concentration of iodine in milk from cows in the 2 herds and from sows Table 1 was prepared. The concentration at the first sampling, 2, 7-8, $12-14,28$ and 49 days after parturition, is presented. The higher concentration of iodine in milk of the sows should be noted.

\section{DISCUSSION}

The observed decrease in the concentration of iodine in milk during the first days after parturition in cows as well as in sows is in agreement with the results of previous studies on milk from these animals performed by Stöckl \& Leskova (1967) and Onderscheka (1969), respectively. Higher concentration of iodine in colostrum than in normal milk of cows has also been reported by Kirchgessner (1959) and Man \& Benotti (1969). Using ${ }^{131}$ I, Bustad et al. (1963) found that the ${ }^{131}$ I-concentration in colostrum was $2-3$ times higher than that in the milk on the 7 th day of lactation. It should be noted that colostrum contains higher concentrations of certain other trace elements, e.g. Fe, $\mathrm{Zn}$, $\mathrm{Co}, \mathrm{Cu}, \mathrm{Ni}, \mathrm{Cr}, \mathrm{Mo}$, than normal milk of the cow (Kirchgessner). Colostrum of the sow has also been shown to have a higher con- 
centration of elements such as $\mathrm{Fe}, \mathrm{Zn}, \mathrm{Cu}$ and Mo than milk sampled later during lactation (Neuhaus 1961, Onderscheka). One may speculate that the higher concentration of iodine as well as of certain other elements in colostrum reflects a high requirement of these elements of the newborn.

The concentration of total iodine in milk of sows is $20-50$ times higher than in the milk of cows at corresponding times up to 14 days after parturition. Four weeks after parturition a tenfold difference was recorded. It is well known that the concentration of iodine in milk is greatly influenced by the iodine intake. Based on data of the composition of the fodder of the 2 herds of cows it can be estimated that in both herds each cow received about $4 \mathrm{mg}$ of iodine per day. The concentration of iodine in milk was on average between 1 and $4 \mu \mathrm{g} / 100 \mathrm{ml}$ at the different sampling times. This is in fairly good agreement with the observations made by Bustad et al. and others (Garner \& Scott Russell 1966) that $0.5-1.0 \%$ of the daily dose of radioiodine is appearing per 1 milk.

The sows in the present study received per day about $1.5 \mathrm{mg}$ iodine. The concentration of iodine in milk was about $67 \mu \mathrm{g} /$ $100 \mathrm{ml}$ at parturition and decreased to about $30 \mu \mathrm{g} / 100 \mathrm{ml} 7$ weeks after parturition. Consequently between 45 and $20 \%$ of the daily dose of iodine was recovered per 1 milk during the sampling period of 7 weeks. The mammary gland has an ability to concentrate iodine in a way very similar to that of the thyroid (Brown-Grant 1961). Whatever mechanism involved, it can be concluded that the cow's udder is inefficient compared with the mammary gland of the sow in this respect. Furthermore the concentration ability at least in the sow seems to be greater immediately after parturition than at later stages of lactation.

Despite the same daily intake of iodine of the cows in the 2 herds, the concentration of iodine in milk of the cows in Herd II was considerably lower than that of Herd I. This difference can be explained by a fairly high percentage of oil crops in the concentrate. Rapeseed meal fed to milking cows has been observed to reduce the concentration of iodine in milk probably depending on the occurrence of glucosinolates in the rapeseed meal (Ekman 1971). Furthermore, Hemken (1970) postulated that soybean protein in some way interferes with the normal iodine metabolism resulting in a lower iodine concentration in the milk.

The increase of iodine concentration in the milk of cows in 
Herd I after a minimum value 2 days after parturition may be explained by a somewhat higher iodine supplementation from that time on. The cows in this herd had free access to a salt block containing $0.005 \%$ iodine.

In summary it can be concluded that besides dietary intake of iodine and goitrogenic substances the stage of lactation may cause a considerable variation in the iodine content of cows' and sows' milk. Furthermore, the mammary gland of the sow has been shown to have a higher ability to concentrate iodine than that of the cow.

\section{REFERENCES}

Brown-Grant, $K$.: Extrathyroidal iodide concentrating mechanisms. Physiol. Rev. 1961, 41, 189-213.

Bustad, L. K., D. H. Wood, E. E. Elefson, H. A. Ragan \& R. O. McClellan: $I^{131}$ in milk and thyroid of dairy cattle following a single contamination event and prolonged daily administration. Health Phys. 1963, 9, 1231-1234.

Ekman, L.: Clinico-chemical and morphological studies of thyroid function in cattle. In Mineral Studies with Isotopes in Domestic Animals. International Atomic Energy Agency, Vienna 1971, $101-109$.

Garner, R. J. \& R. Scott Russell: Isotopes of iodine. In Radioactivity and Human Diet. ed. R. Scott Russell. Pergamon Press, London 1966, 297-315.

Hemken, R. W.: Iodine. J. Dairy Sci. 1970, 53, 1138-1143.

Kirchgessner, M.: Wechselbeziehungen zwischen Spurenelementen in Futtermitteln und tierischen Substanzen sowie Abhängigkeitsverhältnisse zwischen einzelnen Elementen bei der Retention. (The interaction between trace elements in fodder and substance of animal origin as well as the relationship between the retention of certain elements). $Z$. Tierphysiol. Tierernährung $u$. Futtermitt.-k. 1959, 14, 270-277.

Man, E. B. \& J. Benotti: Butanol-extractable iodine in human and bovine colostrum and milk. Clin. Chem. 1969, 15, 1141-1146.

Neuhaus, U.: Die Milchleistung der Sau. (Milk production of the sow). Z. Tierzücht. Züchtungsbiol. 1961, 75, 160-191.

Onderscheka, $K$.: Untersuchungen über Menge und Zusammensetzung der Schweinemilch und der Einfluss dieser Faktoren auf das Wachstum der Ferkel. (Quality and composition of sows' milk in relation to the growth of piglets). Beiheft zur Wien. tierärztl. Mschr. 1969, 56, Heft. 10.

Stöckl, W. \& R. Leskova: Untersuchungen über den Jodgehalt in der Milch und Kolostrum des Rindes. (Studies on the iodine content of cows' milk and colostrum). Milchwiss. 1967, 22, 692694. 


\section{SAMMANFATTNING}

Jodhalten $i$ colostrum och vanlig mjölk från kor och suggor.

Totaljodhalten i colostrum och vanlig mjölk från kor och suggor har bestämts med Technicon Autoanalyzer. Hos såväl kor som suggor observerades en sänkning av jodhalten i mjölk under de första dagarna efter partus. Vid första provtagningstillfället inom åtta timmar efter partus var totaljodkoncentrationen i colostrum från kor i de båda besättningarna i medeltal 3,4 respektive $2,4 \mu \mathrm{g} / 100 \mathrm{ml}$. I colostrum från suggor var jodhalten omedelbart efter partus i medeltal $67 \mu \mathrm{g} /$ $100 \mathrm{ml}$. Med utgångspunkt från foderstaterna beräknas att $0,5-1$ och $20-45 \%$ av det dagliga jodintaget hos kor respektive suggor utsöndras per 1 mjölk eller colostrum. Juvervävnaden hos sugga förefaller vid jämförelse med ko ha en avsevärt högre förmága att koncentrera jod. Koncentrationsmekanismen hos såväl ko som sugga synes vara mer effektiv omedelbart efter partus än senare under laktationen.

(Received January 25, 1972).

Reprints may be requested from: Krister Iwarsson, Department of Clinical Biochemistry, Royal Veterinary College, S-104 05 Stockholm 50, Sweden. 